ISSN $2623-6575$

GLASILO

FUTURE

UDK 60

UDK 631

UDK 630

UDK 336

UDK 338

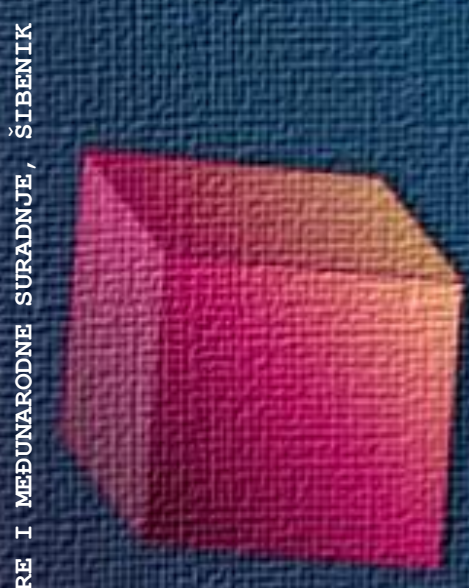

5
5
5

î

s.

䐱

5
5
0
0
0
0
0

A

8

S

竞

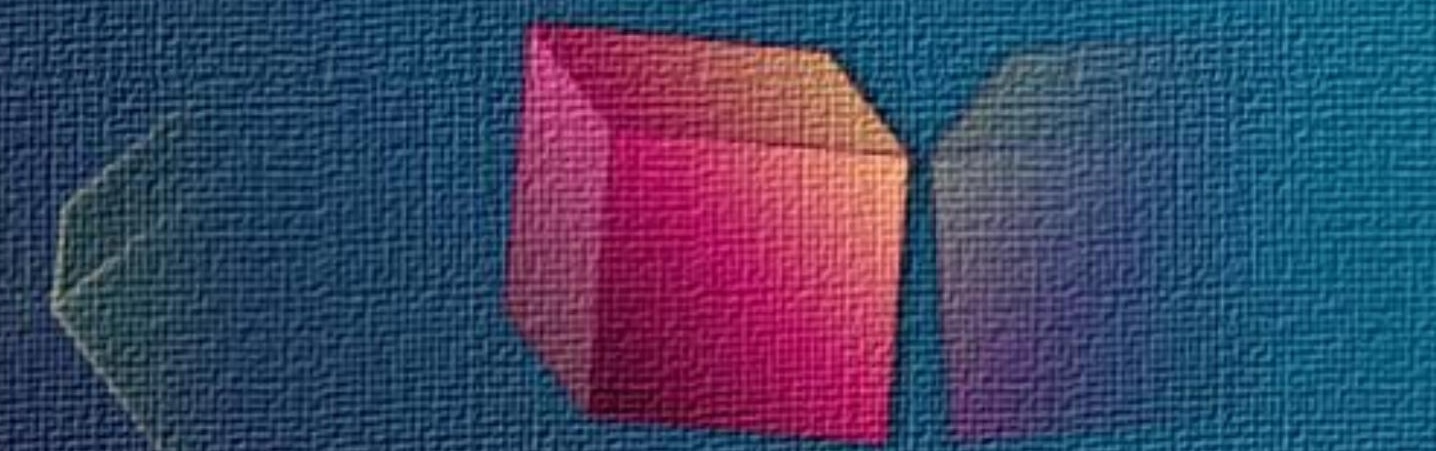

(1) 


\section{Glasilo Future}

\section{Stručno-znanstveni časopis}

Nakladnik: FUTURA

\section{FUTUR}

Sjedište udruge: Šibenik

\section{Adresa uredništva:}

Bana Josipa Jelačića 13 a, 22000 Šibenik, Hrvatska / Croatia 留 / 圆: +385 (0) 022218133

$\triangle$ : urednistvo@gazette-future.eu / editors@gazette-future.eu (3): www.gazette-future.eu

\section{Uređivački odbor / Editorial Board:}

Doc. dr. sc. Boris Dorbić, v. pred. - glavni i odgovorni urednik / Editor-in-Chief

Emilija Friganović, dipl. ing. preh. teh., v. pred. - zamjenica g. i o. urednika / Deputy Editor-in-Chief

Ančica Sečan Matijaščić, mag. act. soc. - tehnička urednica / Technical Editor

Antonia Dorbić, mag. art. - zamjenica tehničke urednice / Deputy Technical Editor

Prof. dr. sc. Željko Španjol

Mr. sc. Milivoj Blažević

Vesna Štibrić, dipl. ing. preh. teh.

\section{Međunarodno uredništvo / International Editorial Board:}

Prof. dr. sc. Kiril Bahcevandziev - Portugal (Instituto Politécnico de Coimbra)

Prof. dr. sc. Martin Bobinac - Srbija (Šumarski fakultet Beograd)

Doc. dr. sc. Zvezda Bogevska - Makedonija (Fakultet za zemjodelski nauki i hrana Skopje)

Dario Bognolo, mag. ing. - Hrvatska (Veleučilište u Rijeci)

Prof. dr. sc. Agata Cieszewska - Poljska (Szkoła Główna Gospodarstwa Wiejskiego w Warszawie)

Dr. sc. Bogdan Cvjetković, prof. emeritus - Hrvatska (Agronomski fakultet Zagreb)

Prof. dr. sc. Duška Ćurić - Hrvatska (Prehrambeno-biotehnološki fakultet Zagreb)

Doc. dr. sc. Margarita Davitkovska - Makedonija (Fakultet za zemjodelski nauki i hrana Skopje)

Doc. dr. sc. Dubravka Dujmović Purgar - Hrvatska (Agronomski fakultet Zagreb)

Prof. dr. sc. Semina Hadžiabulić - Bosna i Hercegovina (Agromediteranski fakultet Mostar)

Prof. dr. sc. Péter Honfi - Mađarska (Faculty of Horticultural Science Budapest)

Prof. dr. sc. Valeria Ivanova - Bugarska (Fakultet za lozaro-gradinarstvo Plovdiv)

Doc. dr. sc. Orhan Jašić - Bosna i Hercegovina (Filozofski fakultet Tuzla)

Prof. dr. sc. Tajana Krička - Hrvatska (Agronomski fakultet Zagreb)

Prof. dr. sc. Biljana Lazović - Crna Gora (Biotehnički fakultet Podgorica)

Prof. dr. sc. Bosiljka Mustać - Hrvatska (Sveučilište u Zadru)

Hrv. akademik prof. dr. sc. Stanislav Nakić - Bosna i Hercegovina (Sveučilište Hercegovina Mostar)

Sandra Popović, mag. ing. - Srbija (Poljoprivredni fakultet Beograd)

Doc. dr. sc. Bojan Simovski - Makedonija (Šumarski fakultet Skopje)

Prof. dr. sc. Davor Skejić - Hrvatska (Građevinski fakultet Zagreb)

Doc. dr. sc. Milan Stanković - Srbija (Univerzitet u Kragujevcu)

Akademik prof. dr. sc. Refik Šećibović - Bosna i Hercegovina (Visoka škola za turizam i menadžment Konjic)

Prof. dr. sc. Andrej Šušek - Slovenija (Fakulteta za kmetijstvo in biosistemske vede Maribor)

Prof. dr. sc. Elma Temim - Bosna i Hercegovina (Agromediteranski fakultet Mostar)

Doc. dr. sc. Ivana Vitasović Kosić - Hrvatska (Agronomski fakultet Zagreb)

Doc. dr. sc. Ana Vujošević - Srbija (Poljoprivredni fakultet Beograd)

Prof. dr. sc. Vesna Židovec - Hrvatska (Agronomski fakultet Zagreb)

Lektura i grafička priprema: Ančica Sečan Matijaščić, mag. act. soc.

Objavljeno: 31. prosinca 2018. godine.

Časopis izlazi u elektroničkom izdanju dva puta godišnje, krajem lipnja i prosinca, a predviđena su i dva interdisciplinarna specijalna izdanja tijekom godine iz STEM i ostalih znanstvenih/umjetničkih područja.

Časopis je besplatan. Rukopisi i recenzije se ne vraćaju i ne honoriraju.

Umnožavanje (reproduciranje), stavljanje u promet (distribuiranje), priopćavanje javnosti, stavljanje na raspolaganje javnosti odnosno prerada u bilo kojem obliku nije dopuštena bez pismenog dopuštenja Nakladnika. Sadržaj objavljen u Glasilu Future može se slobodno koristiti u osobne i obrazovne svrhe uz obvezno navođenje izvora. 


\section{Glasilo Future}

\section{Stručno-znanstveni časopis}

FUTURA - stručno-znanstvena udruga za promicanje održivog razvoja, kulture i međunarodne suradnje, Bana Josipa Jelačića 13 a, 22000 Šibenik, Hrvatska

(2018) 1 (4) 01-54

\section{SADRŽAJ:}

Izvorni znanstveni rad (original scientific paper)

Str.

B. Dorbić, Sandra Dukić, Emilija Friganović, Margarita Davitkovska,Zvezda Bogevska, Ana Vujošević, Sandra Popović

Percepcije i stavovi o ukrasnim karakteristikama i primjeni submediteranskog

listopadnog drveća u zimskom razdoblju

Perceptions and attitudes about ornamental characteristics of sub-mediterranean

deciduous trees during the winter season

\section{Stručni rad (professional paper)}

\section{Z. Maričić, L. Maričić}

Optimiziranje portfelja s različitim brojem imovine i različitim preferencijama rizika Portfolio optimization with different number of assets and different risk preferences

L. Maričić, Z. Maričić

Utjecaj dodatnih dionica na granice efikasnosti, portfelj s minimalnom varijancom i tangencijalni portfelj

Influence of additional shares on efficiency frontier, minimum variance portfolio and tangential portfolio

\section{Nekategorizirani rad (uncategorised paper)}

\section{B. Dorbić}

Prikaz knjige

Book review

\section{B. Dorbić}

Društvene vijesti

Social news 
L. Maričić, Z. Maričić / Utjecaj dodatnih dionica na granice efikasnosti, portfelj s minimalnom varijancom i tangencijalni portfelj / Glasilo Future (2018) 1 (4) 31-44

\title{
Utjecaj dodatnih dionica na granice efikasnosti, portfelj s minimalnom varijancom i tangencijalni portfelj
}

\section{Influence of additional shares on efficiency frontier, minimum variance portfolio and tangential portfolio}

\author{
Luka Maričići ${ }^{*}$, Zoran Maričić ${ }^{2}$
}

stručni rad (professional paper)

doi: $10.32779 / g f .1 .4 .3$

\section{Sažetak}

Ovaj rad se nastavlja na rad "Optimiziranje portfelja s različitim brojem imovine i različitim preferencijama rizika". Koristeći suvremenu teoriju portfelja Harryja Markowitza za stvaranje efikasnih portfelja unaprijed odabranih dionica pokazali smo kako nastaje efikasna granica od četiri izabrane dionice (Grupa 1.) s hrvatskog tržišta kapitala, sektor turizma. U toj grupi su dionice Valamar riviera (RIVP), Arena hospitality group (ARNT), Adris grupa (ADRS) i Liburnia riviera hoteli (LRH). Izračunati su ponderi za svaku dionicu koji definiraju portfelj s minimalnom varijancom i tangencijalni portfelj. U ovom radu toj grupi dodajemo novu dionicu iz različitih sektora hrvatske ekonomije: Ericsson Nikola Tesla (ERNT), Hrvatski telekom (HT) i Zagrebačka banka (ZABA). Dodajući pojedinu dionicu našim postojećim četirima dionicama izračunavamo i analiziramo kako to utječe na granicu efikasnosti i portfelj s minimalnom varijancom te tangencijalni portfelj, pokazujemo koja dionica najbolje odgovara danoj grupi u smislu smanjenja volatilnosti rezultata. Grafovi i izračuni pokazuju kako se rezultati mijenjaju kada se pojedina dionica ove grupe uključi u postojeću grupu turističkog sektora. Rezultati jasno pokazuju kako treba znati koju dionicu uključiti u postojeću grupu te koja najbolje pridonosi rezultatima portfelja.

Ključne riječi: portfelj, granica efikasnosti, portfelj s minimalnom varijancom, tangencijalni portfelj.

\begin{abstract}
This paper is extension to work "Portfolio optimization with different number of assets and different risk preferences". Using Modern portfolio theory of Harry Markowitz for build-up efficient portfolio of forehand chosen stocks we have made efficient frontier consisted of four chosen stocks (Group 1) from Croatian capital market, tourism industry. This group includes stocks of Valamar riviera (RIVP),

\footnotetext{
${ }^{1}$ Wirtschaftsuniversität Wien, Welthandelsplatz 1, 1020 Wien, Republika Austria.

* Luka Maričić, BA oec., e-mail: lukamaricic11@gmail.com.

${ }^{2}$ Veleučilište "Marko Marulić" u Kninu, Krešimirova 30, 22300 Knin, Republika Hrvatska.
} 
Arena hospitality group (ARNT), Adris grupa (ADRS) and Liburnia riviera hoteli (LRH). We have calculated weights for each stock in efficient portfolio with minimum variance and tangent portfolio. In this paper, we add to that group a new stock from different industry of Croatian economy: Ericsson N. Tesla (ERNT), Hrvatski telekom (HT) i Zagrebačka banka (ZABA). By adding a new stock to our existing four stocks, we calculated and analyzed impact on efficient frontier and minimum variance portfolio as well tangent portfolio showing which stock best suits to that group in the sense of volatility results decrease. Graphs and calculations show change of results resulting from inclusion of every single stock in existing group of tourism sector stocks. Results clearly show that one should know which stock to include in existing group and which one best contributes to portfolio results.

Key words: portfolio, efficient frontier, minimum variance portfolio, tangent portfolio.

\section{Uvod}

U ovom radu koristi se moderna teorija portfelja (MPT) koja se zasniva na radu H. M. Markowitza koji je 1952. bez pomoći suvremenih kompjutera pokazao zašto se investitori koji žele efikasni portfelj (koji minimizira rizik uz željeni prinos ili povećava prinos uz dani rizik) ne mogu osloniti samo na kriterij prinos-varijanca.

Moderna teorija portfelja u idealnom svijetu počiva na pretpostavci racionalnog ponašanja investitora nesklonih riziku koji djeluju na razumno efikasnom tržištu kapitala (ne i savršeno efikasnom). Na takvom tržištu oni mogu procijeniti vjerojatnu profitabilnost investicije preko statističke analize vaganih očekivanih prinosa na osnovi normalne distribucije (Hill, 2010; Luemberger, 1998).

Racionalni, riziku neskloni investitori očekuju maksimalni prinos uz dani nivo rizika ili dani prinos uz minimalni rizik. Ukupni rizik se mjeri varijancom (ili standardnom devijacijom) kao kvadratom odstupanja prinosa od ukupnog očekivanog (prosječnog) vaganog prinosa. Koristeći kriterije efikasnosti na bazi odnosa prinos-varijanca investitor može donijeti tri odluke kod upravljanja portfeljem investicija ovisno o rezultatu pojedinačne investicije u portfelju. Znači može njome trgovati (kupiti nove ili prodati postojeće), ne činiti ništa (zadržati postojeće stanje) ili izvršiti zamjenu (npr, zamijeniti dionicu s obveznicom).

Prema Markowitzu (1952) rizik portfelja može se znatno smanjiti, ali ne i eliminirati, ne kompromitirajući ukupni prinos, tako da portfelj diversificiramo tj. u njega uključimo optimalnu kombinaciju vrijednosnica. Znači treba ulagati u brojne vrijednosnice, a ne "sva jaja staviti u jednu košaru". Uključujući što veći broj vrijednosnica u portfelj, značaj varijance pojedine dionice kao mjere rizika opada, a raste utjecaj kovarijance kao mjere varijabilnosti kombinacije prinosa svake vrijednosnice oko njihove sredine (Bodie, 2006; Maričić, 2010).

Ovisno o stanju rizika i prinosa, logika same kovarijance je jednostavna: 
L. Maričić, Z. Maričić / Utjecaj dodatnih dionica na granice efikasnosti, portfelj s minimalnom varijancom i tangencijalni portfelj / Glasilo Future (2018) 1 (4) 31-44

- ako su prinosi dvije investicije neovisni tada nema primjetne veze te se na osnovu jedne ne može predvidjeti drugu.

- ako su prinosi ovisni o vezi koja postoji između investicija i kovarijanca će imati negativnu ili pozitivnu vrijednost koja utječe na rizik portfelja, čime slijedi:

1. kada je odstupanje od sredine svake od uparenih dionica negativno, njihov produkt je pozitivan pa tako i kovarijanca;

2. kada je odstupanje od sredine pozitivno, kovarijanca je i dalje pozitivna;

3. kada je odstupanje od sredine jedne od uparenih dionica negativno tada je njihova kovarijanca negativna.

Znači u ekonomskim situacijama, gdje su pojedinačni prinosi dionica neovisni i gdje ne postoji savršena pozitivna korelacija, rizik smanjujemo diversifikacijom bez utjecaja na ukupni prinos.

Daljnji razvoj moderne teorije portfelja vodio je ka spoznaji da se ukupni rizik vrijednosnice (mjeren varijancom) unutar diversificiranog portfelja može podijeliti na sistematski i nesistematski rizik.

Drugi se može znatno smanjiti diversifikacijom, a prvi ne može te on utječe na čitavi tržišni portfelj vrijednosnica.

Ovaj rizik se naziva i tržišni rizik. To je jedini rizik za koji investitori dobivaju nagradu (premiju) da bi ih se privoljelo da ulažu u rizične vrijednosnice. On mjeri odnos rizika pojedine vrijednosnice $\mathrm{i}$ rizika čitavog tržišta kapitala koji je po definiciji 1. Ta mjera naziva se beta koeficijent.

Na osnovi tržišne cijene rizika (bete) razvijen je Model određivanja cijena na tržištu kapitala (engleski akronim CAPM) (Hill, 2013).

Na bazi ovog pristupa, u ovom radu, pokazat ćemo kao se mijenja granica učinkovitosti [efficient frontier (eng.)] kombinirajući dionice iz Grupe 1. (dionice turističkog sektora) s drugim dionicama iz različitih sektora hrvatske ekonomije te vidjeti koje dionice vrijedi uključiti, a koje ne vrijedi u kombinirani portfelj.

Ovaj pristup, napravljen na bazi historijskih prinosa dionica sa zagrebačke burze, problematičan je zbog pretpostavke da možemo očekivati da će se prinosi dionica u budućnosti kretati u skladu sa svojim povijesnim kretanjem. Iako je ovo problematično, mi jedino možemo povijesne prinose koristiti kao najbolju mjeru budućih prinosa. 


\section{Materijali i metode}

U ovom radu, koristeći modernu teoriju portfelja, gradimo efikasne granice tako da portfelju koji se sastoji od četiri dionice turističkog sektora dodajemo po jednu novu iz različitih sektora hrvatske ekonomije.

Svrha je preko promjena granica učinkovitosti pokazati utjecaj diversifikacije na portfelj koji se sastoji od Grupe 1. i nove dionice iz različitog sektora ekonomije te pokazati koja nam dionica u portfelju najbolje odgovara tj. u kojoj kombinaciji imamo najbolji odnos rizika i prinosa te Sharpeov omjer.

$\mathrm{Na}$ grafu pokazujemo granice efikasnosti [efficient frontier (eng.)] portfelja Grupe 1. i nove dionice te zatim izračunavamo prinos, standardnu devijaciju i Sharpeov omjer za portfelj s minimalnom varijancom i tangencijalni portfelj s dodavanjem jedne nove dionice.

\section{Zadatak}

Rad je temeljen na zadatku kako slijedi.

Četirima dionicama turističkog sektora dodajemo svaki put jednu novu dionicu iz različitih sektora hrvatske ekonomije. To su:

a) Ericsson Nikola Tesla (ERNT)

Ericsson Nikola Tesla je vodeća hrvatska tehnološka kompanija fokusirana na područje telekomunikacijskih proizvoda i rješenja. Sjedište joj je u Zagrebu.

b) Hrvatski Telekom (HT)

Hrvatski Telekom je vodeća telekomunikacijska kompanija u Hrvatskoj. Sjedište joj je u Zagrebu.

c) Zagrebačka Banka (ZABA)

Zagrebačka banka je najveća banka u Hrvatskoj. Sjedište joj je u Zagrebu.

Dionice iz ove grupe su iz različitih sektora, što demonstrira diversifikaciju kroz više sektora.

Promatrani period je 5 godina, od 01. 01. 2012. do 31. 12. 2016.

Korišteni podatci su dnevni prinosi. Sve jedinice u računanjima (prinosi, varijance, standardne devijacije, kovarijance) su prikazane anualizirane. Izvor podataka je web stranica Zagrebačke burze (Zagrebačka burza). Glavni zadatak rada je pokazati kako se mijenjaju granice efikasnosti, portfelj s minimalnim rizikom i tangencijalni portfelji s dodavanjem jedne nove dionice postojećim dionicama te koji parametri određuju te promjene (Damodaran, 2015). 
Pretpostavke su sljedeće:

1) nema dionica bez rizične kamatne stope;

2) nema transakcijskih troškova;

3) nema kratke prodaje [short-selling (eng.)];

4) nema poreza ni naknada.

\section{Rezultati istraživanja}

\section{Praktična otkrića i analiza}

\section{a) Ericsson Nikola Tesla}

U ovom koraku dodajemo po jednu dionicu nove grupe, a najprije dionicu ERNT.

Prvo moramo pomoću M. S. Excela izračunati kovarijance između ERNT i dionica Grupe 1.

Podatci su navedeni (godišnji) u Tablici 1.

Tablica 1. Tablica kovarijanci između ERNT i dionica Grupe 1.

Table 1. Table of covariance between ERNT and Group 1 shares.

\begin{tabular}{|l|r|}
\hline & \multicolumn{1}{|c|}{ ERNT } \\
\hline RIVP & 0,000156465 \\
\hline ARNT & $-0,00311098$ \\
\hline ADRS & $-0,000299914$ \\
\hline LRH & $-0,001588574$ \\
\hline
\end{tabular}

Pomoću ovih informacija, kao i podataka iz Grupe 1, a pomoću Excel Solvera, dobit ćemo za granicu efikasnosti (učinkovitosti) 5 dionica (Grupa 1 + ERNT) rezultat kako slijedi.

Portfelj s minimalnom varijancom:

- očekivani prinos 0,203617056 ;

- standardna devijacija 0,174139639 ;

- sharpe omjer (nagib) 1,169274611 .

Da bi ga se ostvarilo potrebni su sljedeći udjeli (ponderi):

- RIVP 0,06652115;

- ARNT 0,12839692;

- ADRS 0,28362459;

- LRH 0,09675332;

- ERNT 0,42470401. 
Dionica ERNT-a ima prilično veliku važnost u portfelju s minimalnom varijancom, s najvećim udjelom od svih pet dionica, koji iznosi $42,47 \%$. Standardna devijacija je pala s 23,13\% na 17,41 \%, što čini veliku razliku i to pozitivnu razliku.

Općenito govoreći, može se reći da je utjecaj dionice ERNT-a na portfelj minimalne varijance jako velik.

Tangencijalni portfelj:

- očekivani prinos 0,432212887 ;

- standardna devijacija 0,239061968;

- Sharpe omjer (nagib) 1,807953351 .

Da bi ga se ostvarilo potrebni su sljedeći udjeli:

- RIVP 0,1288572;

- ARNT 0,31775014;

- ADRS 0,45400428;

- LRH 0,09938841;

- ERNT 0.

Dionica ERNT-a nije prisutna u tangencijalnom portfelju. Nagib je ostao isti (u usporedbi s Grupom 1.).

Općenito, može se reći da učinci ERNT dionice na tangencijalni portfelj ne postoje.

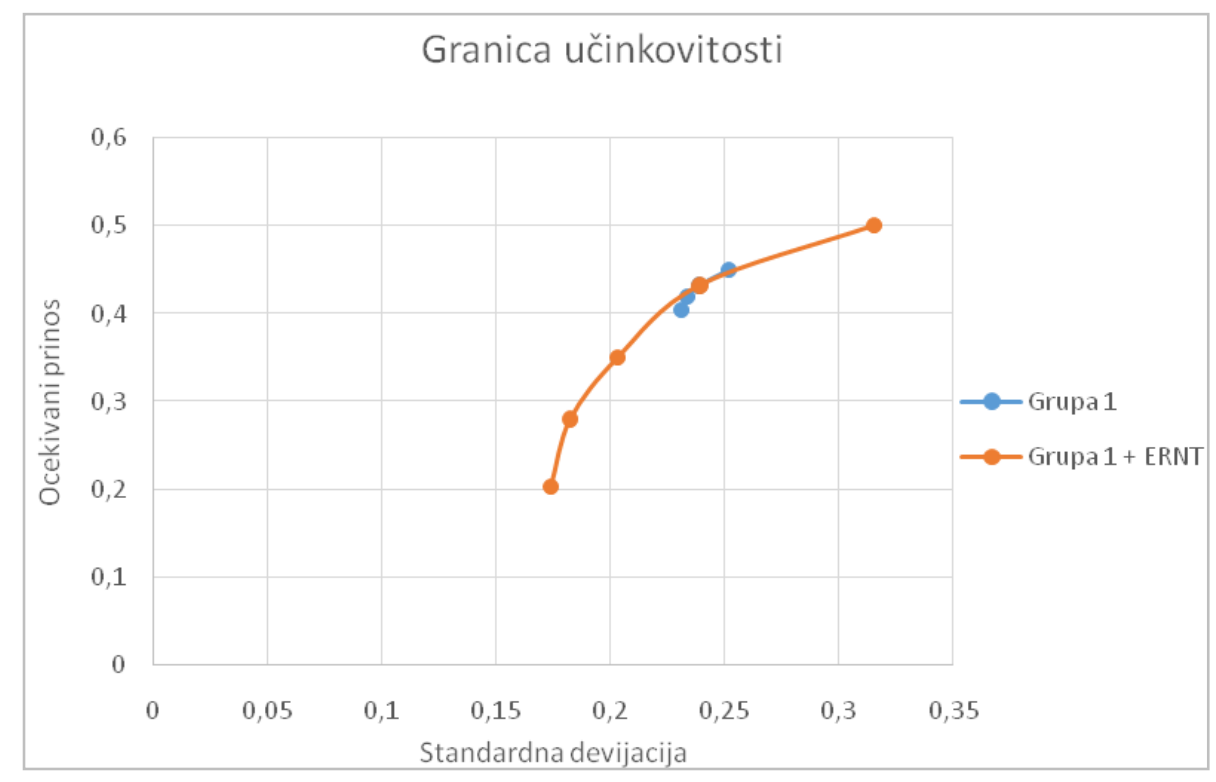

Slika 1. Grafički prikaz granice učinkovitosti za Grupu $1+$ ERNT portfelj u usporedbi s granicom učinkovitosti portfelja Grupe 1.

Figure 1. Graph - efficiency frontier of Group $1+$ ERNT portfolio compared to Group 1 portfolio efficiency frontier. 
Graf (Slika 1.) prikazuje granicu učinkovitost za Grupu 1. + ERNT portfelj u usporedbi s granicom učinkovitosti portfelja Grupe 1.

\section{b) Hrvatski telekom (HT)}

Kao i u prethodnom primjeru, najprije se izračunavaju kovarijance između HT-a i dionica Grupe 1.

One su navedene (analizirane) u Tablici 2.

Tablica 2. Tablica kovarijanci između HT i dionica Grupe 1.

Table 2. Table of covariance between HT and Group 1 shares.

\begin{tabular}{|l|r|}
\hline & HT \\
\hline RIVP & $-0,003539877$ \\
\hline ARNT & 0,005210209 \\
\hline ADRS & 0,001495024 \\
\hline LRH & 0,000686832 \\
\hline
\end{tabular}

Koristeći ove informacije, kao i podatke iz Grupe 1., dobivamo za granicu učinkovitosti 5 dionica (Grupa $1+$ HT) rezultat kako slijedi.

Portfelj s minimalnom varijancom:

- očekivani prinos 0,126594002 ;

- standardna devijacija 0,159661609;

- Sharpe omjer (nagib) 0,792889429 .

Da bi ga se ostvarilo potrebni su sljedeći udjeli:

- RIVP 0,05999062;

- ARNT 0,09051736;

- ADRS 0,23127820;

- LRH 0,07883294;

- HT 0,53938088.

Dionica HT-a je najvažnija dionica u portfelju minimalne varijance, ima najveći udio od svih pet dionica sa 53,94 \%. Standardna devijacija je pala sa $23,13 \%$ na $15,97 \%$, što čini veliku razliku.

Općenito, može se reći da je utjecaj dionice HT-a na portfelj minimalne varijance jako visok.

Tangencijalni portfelj:

- očekivani prinos 0,432212816 ;

- standardna devijacija 0,239061929;

- Sharpe omjer (nagib) 1,807953351. 
Da bi ga se ostvarilo potrebni su sljedeći udjeli:

- RIVP 0,12885711;

- ARNT 0,31774981;

- ADRS 0,45400478;

- LRH 0,09938829;

- HT 0.

Dionica HT-a također nije prisutna u tangencijalnom portfelju. Nagib je također ostao isti (u usporedbi s Grupom 1.).

Općenito, može se reći da učinci dionice HT-a na tangencijalni portfelj ne postoje, jednako kao i u prethodnom slučaju.

Graf (Slika 2.) prikazuje granicu učinkovitosti za Grupu 1. + HT portfelj u usporedbi s granicom učinkovitosti portfelja Grupe 1.

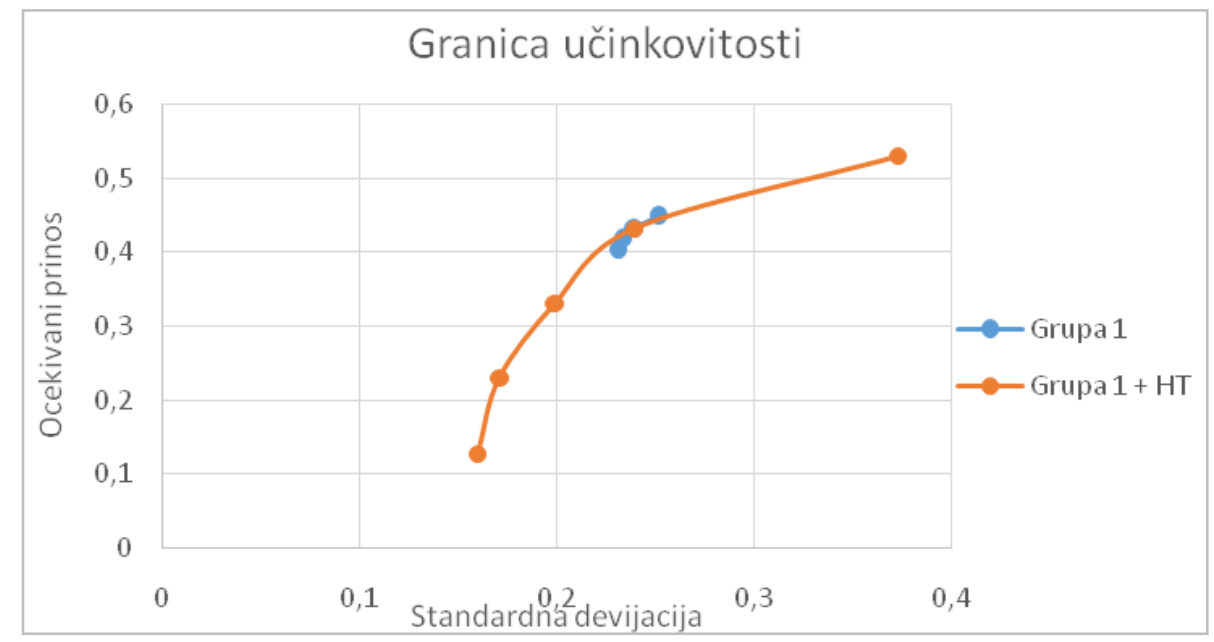

Slika 2. Grafički prikaz granice učinkovitosti za Grupu $1+$ HT portfelj u usporedbi s granicom učinkovitosti portfelja Grupe 1.

Figure 2. Graph - efficiency frontier of Group $1+H T$ portfolio compared to Group 1 portfolio efficiency frontier.

\section{c) Zagrebačka banka (ZABA)}

Tablica 3. Tablica kovarijanci između ZABA i dionica Grupe 1.

Table 3. Table of covariance between ZABA and Group 1 shares.

\begin{tabular}{|l|r|}
\hline & \multicolumn{1}{|c|}{ ZABA } \\
\hline RIVP & $-0,003315925$ \\
\hline ARNT & 0,001343129 \\
\hline ADRS & 0,000579491 \\
\hline LRH & $-0,024725452$ \\
\hline
\end{tabular}


Pomoću M. S. Excel Solvera dobili smo rezultate kako slijedi.

Portfelj s minimalnom varijancom:

- očekivani prinos 0,332271427 ;

- standardna devijacija 0,200228793;

- Sharpe omjer (nagib) 1,65945878 .

Da bi ga se ostvarilo potrebni su sljedeći udjeli:

- RIVP 0,0897438;

- ARNT 0,15964284;

- ADRS 0,37078723;

- LRH 0,14631224;

- ZABA 0,23351391.

Dionica ZABA-e ima vrlo veliku važnost u portfelju s minimalnom varijancom, ima drugi najveći udio od svih pet dionica sa 23,35 posto.

Standardna devijacija je pala: s $23,13 \%$ na 20,02 \%, što ukazuje da je dodavanje ZABA-e znatno unaprijedilo portfelj s minimalnom varijancom.

Općenito govoreći, može se reći da je utjecaj dionice ZABA-e na portfelj minimalne varijance poprilično visok.

Tangencijalni portfelj:

- očekivani prinos 0,404544787 ;

- standardna devijacija 0,220934398;

- Sharpe omjer (nagib) 1,831062931 .

Da bi ga se ostvarilo potrebni su sljedeći udjeli:

- RIVP 0,11813149;

- ARNT 0,28912691;

- ADRS 0,41307013;

- LRH 0,09816904;

- ZABA 0,08150244 .

Dionica ZABA je malo prisutna u tangentnom portfelju, ali ne u istoj mjeri kao u portfelju minimalne varijance, u usporedbi s njim je njen udio otprilike tri puta manji.

Nagib je porastao sa 1,807953351 na 1,831062931 , što je mali ali koristan napredak. 
Graf (Slika 3.) prikazuje granicu učinkovitosti za Grupu 1. + ZABA portfelj u usporedbi s granicom učinkovitosti portfelja Grupe 1.

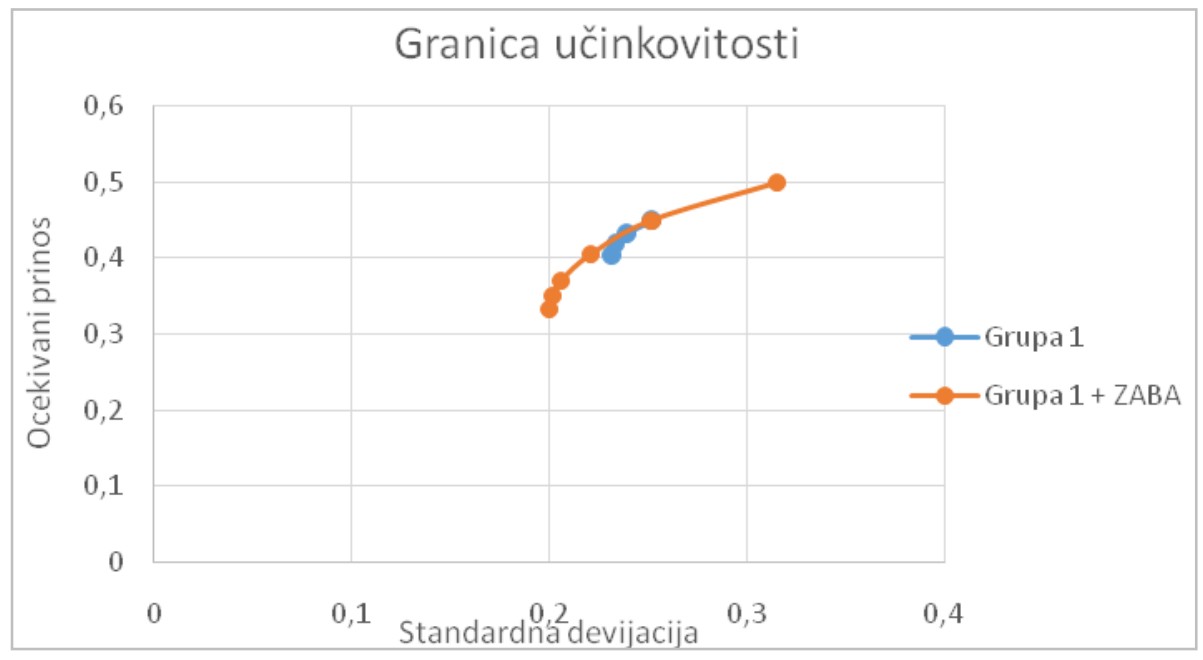

Slika 3. Grafički prikaz granice učinkovitosti za Grupu $1+$ ZABA portfelj u usporedbi s granicom učinkovitosti portfelja Grupe 1.

Figure 3. Graph - efficiency frontier of Group $1+$ ZABA portfolio compared to Group 1 portfolio efficiency frontier.

\section{Portfelj svih dionica}

Posljednji zadatak ovog rada je stvaranje granice učinkovitosti svih dionica. Rezultati ovog izračuna su prikazani u tablici kovarijanci (Tablica 4.).

Tablica 4. Tablica kovarijanci za sve dionice.

Table 4. Table of covariance for all shares.

\begin{tabular}{|l|c|c|r|r|r|r|r|}
\hline & RIVP & \multicolumn{1}{c|}{ ARNT } & \multicolumn{1}{c|}{ ADRS } & \multicolumn{1}{c|}{ LRH } & \multicolumn{1}{c|}{ ERNT } & \multicolumn{1}{c|}{ HT } & \multicolumn{1}{c|}{ ZABA } \\
\hline RIVP & 0,480409 & 0,001800 & $-0,006843$ & 0,000011 & 0,000156 & $-0,003540$ & $-0,003316$ \\
\hline ARNT & & 0,220935 & 0,007471 & 0,010748 & $-0,003111$ & 0,005210 & 0,001343 \\
\hline ADRS & & & 0,101668 & 0,011495 & $-0,000300$ & 0,001495 & 0,000579 \\
\hline LRH & & & & 0,272591 & $-0,001589$ & 0,000687 & $-0,024725$ \\
\hline ERNT & & & & & 0,072875 & $-0,001995$ & $-0,003083$ \\
\hline HT & & & & & & 0,046039 & 0,004284 \\
\hline ZABA & & & & & & & 0,186625 \\
\hline
\end{tabular}

Objašnjenje kratica dionica:

RIVP - VALAMAR RIVIERA

ARNT - ARENA HOSPITALITY GROUP

ADRS - ADRIS GRUPA

LRH - LIBURNIA RIVIERA HOTELI

ERNT - ERICSSON NIKOLA TESLA

HT - HRVATSKI TELEKOM

ZABA - ZAGREBAČKA BANKA 
Portfelj s minimalnom varijancom:

- očekivani prinos 0,078645326 ;

- standardna devijacija 0,12863463 ;

- Sharpe omjer (nagib) 0,611385352 .

Da bi ga se ostvarilo potrebni su sljedeći udjeli:

- RIVP 0,03948637;

- ARNT 0,0611609;

- ADRS 0,14905166;

- LRH 0,06093612;

- ERNT 0,24507032;

- HAT 0,35178573;

- ZABA 0,09250887.

Ovo je izrazito dobar portfelj za investitora koji ne voli rizik jer dominiraju dionice s niskim prinosom i niskim standardnim devijacijama, kao što su ERNT i HT.

Tangencijalni portfelj:

- očekivani prinos 0,404545786 ;

- standardna devijacija 0,220934944;

- Sharpe omjer (nagib) 1,831062931.

Da bi ga se ostvarilo potrebni su sljedeći udjeli:

- RIVP 0,11813028;

- ARNT 0,28913004;

- ADRS 0,41307061;

- LRH 0,09816811;

- ERNT 0;

- HAT 0;

- ZABA 0,08150096.

Ovo je portfelj s najvišim prinosom prilagođenom riziku. Ovdje dominiraju dionice ADRS i ARNT jer imaju visoke očekivane prinose.

Graf (Slika 4.) prikazuje granicu učinkovitosti svih dionica u usporedbi sa svim ostalim korištenim granicama učinkovitosti. 


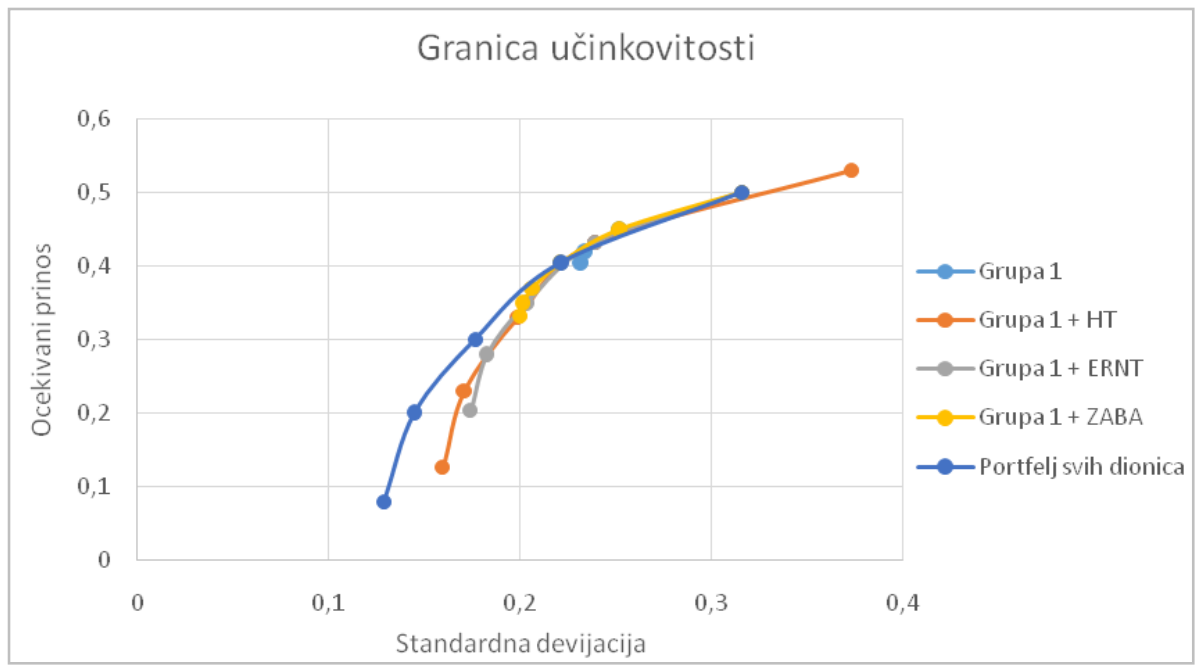

Slika 4. Grafički prikaz granice učinkovitosti svih dionica u usporedbi sa svim ostalim korištenim granicama učinkovitosti.

Figure 4. Graph-efficient frontier of all shares compared to all other efficiency frontier used.

\section{Rasprava i zaključak}

Ovaj rad temelji se na Markowitzovom pristupu, a to znači da uzima u obzir samo dvije varijable, očekivani prinos i standardnu devijaciju.

Te dvije varijable su naša predviđanja o budućnosti koja se temelje na povijesnim podatcima, no veliko je pitanje da li je moguće procijeniti budućnost na bazi prošlosti. Ovaj pristup zanemaruje mogućnost promjene stanja na tržištu (Soros, 2003).

Drugi upitan aspekt je da ovaj pristup koristi samo tehničku, a ne fundamentalnu analizu. Kod tehničke analize pretpostavka je da su svi podatci prisutni u cijeni dionice te se ne ispituju fundamentalne varijable (profit, tržišni udio, prodaja, kompetencije glavne uprave i dr.). On nam može reći koliko je velika šansa da se nešto dogodi, ali ne i zašto bi se to moglo dogoditi (Early, 2017).

Zastupnici ove teorije tvrde da su svi ti podatci već uključeni u cijenu i da tržište uvijek najbolje zna što je "fer vrijednost". Ta se hipoteza zove "hipoteza tržišne efikasnosti" (Tanous, 1997).

Povijest nam može pokazati nekoliko suprotnih primjera, npr. "manija tulipana" u Nizozemskoj (Von Petersdorff, 2008), dot. com manija s početka devedesetih godina dvadesetog stoljeća i dr. Znanstvenici su identificirali mnoge anomalije na tržištu kapitala.

Iako Markowitzev pristup ima sve te nedostatke, popularan je zbog svoje jednostavnosti i jasnoće.

Na temelju rezultata, potvrđeno je da više dionica u portfelju poboljšava portfelj. To pokazuje važnost diversifikacije za racionalnog i riziku nesklonog investitora (Bernstein, 1998). 
Najznačajniji uvid ovog rada je činjenica da je portfelj svih dionica jednak ili bolji od bilo kojeg drugog portfelja za bilo koji željeni prinos ili standardnu devijaciju.

To pokazuju podatci o tangencijalnom portfelju:

- očekivani prinos 0,404545786;

- standardna devijacija 0,220934944;

- Sharpe omjer (nagib) 1,831062931 .

U njemu je osim dionica Grupe 1. uključena samo dionica ZABA.

Dakle, pri odlučivanju između različitih portfelja, uvijek je dobro odabrati portfelj koji sadrži što više dionica.

\section{Literatura}

Bodie, Z., Kane, A., Marcus, A. J. (2006). Počela ulaganja. Zagreb: Mate.

Bernstein, P. (1998). Against the Gods: The Remarkable Story of Risk. New Jersey: John Whiley and Sons, Inc., Hoboken.

Damodaran, A. (2015). Damodaran on Valuation: Security Analysis for Investment and Corporate Finance. New Jersey: John Whiley and Sons, Inc., Hoboken.

Early, J. (2017). Fundamental Analysis. Posjećeno 01. 05. 2017. na mrežnoj stranici Investopedia: http://www.investopedia.com/university/fundamentalanalysis.

Hill, R. A. (2010). Portfolio Theory \& Financial Asnalyses: Exercises. London: Robert Alan Hill \& Ventus Publishing ApS.

Hill, R. A. (2013). The Capital Asset Pricing Model. London: Robert Alan Hill \& bookboon.com.

Luenberger David G. (1998). Investment Science. New York: Oxford University Press.

Maričić, Z. (2010). Financijska tržišta i investicije. Knin: Veleučilište Marko Marulić u Kninu.

Markowitz, H. (1952). Portfolio Selection. Journal of Finance, 7(1), 77-91.

Soros, G., Volcker, A. (2003). The Alchemy of Finance. New Jersey: John Whiley and Sons, Inc., Hoboken.

Tanous, P. (1997). An Interview with Eugene Fama. Posjećeno 01. 05. 2017. na mrežnoj stranici Internet Archive: https://web.archive.org/web/20030108202328/http://library.dfaus.com/reprints/ interview_fama_tanous/. 
Von Petersdorff, W. (2008). Eine Blumenzwiebel für 87.000 Euro. Posjećeno 01. 05. 2017. na mrežnoj stranici Frankfurter Allgemeine Zeitung: http://www.faz.net/aktuell/finanzen/fonds-mehr/historischefinanzkrisen-niederlande-1637-eine-blumenzwiebel-fuer-87-000-euro-1283731.html.

Zagrebačka burza (2017). Posjećeno 01. 05. 2017. na mrežnoj stranici Zagrebačke burze: http://zse.hr.

Primljeno: 17. prosinca 2018. godine

Prihvaćeno: 31. prosinca 2018. godine
Received: December 17, 2018

Accepted: December 31, 2018 